\title{
The Role of Human Resource Management (HRM) in Building Industrial Relation
}

\author{
Vika Anjani*, Agus Subianto and Rini Fatmawati \\ Universitas Hang Tuah \\ *Email: rini.fatmawati@hangtuah.ac.id
}

\begin{tabular}{|c|}
\hline Published: 30/09/2021 \\
\hline How to cite (in APA style): \\
\hline $\begin{array}{l}\text { Anjani, V., Subianto, A., Fatmawati, R. (2021). The Role of Human Resource Management (HRM) in Building Industrial } \\
\text { Relation. Jurnal Ekonomi dan Bisnis Jagaditha, 8(2), 164-171. doi: https://doi.org/10.22225/jj.8.2.2021.164-171 }\end{array}$ \\
\hline
\end{tabular}

\begin{abstract}
In industrial relations, the role of workers is represented by the union as a forum to voice and accommodate aspirations in the rights and obligations of workers. Meanwhile, the owners of capital are represented by human resource management (HRM), which acts as the manager of the company's assets in order to achieve ideal industrial relations. The purpose of this study is to explore the role of human resource management in fostering industrial relations. This is motivated by a violation of high work discipline, which has an impact on industrial relations involving management and trade unions. This study used a qualitative method. The data of this study consists of primary data and secondary data. The primary data are obtained from the direct interviews with related parties at PT PAL Indonesia (Persero) and the secondary data are obtained from various written sources. The results of this study showed that the management is already at the stage of cooperation, where trade unions and management work together in fostering industrial relations. This is done through the handling and resolution of employee complaints.
\end{abstract}

Keywords: industrial relations; trade unions; qualitative research

\section{INTRODUCTION}

Industrial relations are working relationships that involve all related parties based on the interests of production or the interests of the company's goals (Simanjutak, 2003). The parties, who have an interest here, among others, are employees and owners of capital. In industrial relations, the role of workers is represented by the union as a forum to voice and accommodate aspirations in the rights and obligations of workers. Meanwhile, the owners of capital are represented by human resource management (HRM), which acts as the manager of the company's assets in order to achieve ideal industrial relations. Industrial relations are very important for both, because they determine the continuity and success of each other. A conducive relationship between the owners of capital and their workers is the main key to avoid termination of employment (Bahasa Indonesia: Pemutusan Hubungan Kerja/PHK) and improve the welfare of workers as well as expand new job opportunities. This harmonious relationship can be achieved by applying the rules that have been determined and mutually agreed upon in the Collective Labor Agreement (Bahasa Indonesia: Perjanjian Kerja Bersama/PKB). However, it is undeniable that conflicts or disputes often occur between the two, despite the existence of a PKB, as happened to PT PAL Indonesia (Persero) in 2019. 
The Role of Human Resource Management (HRM) in Building Industrial Relation

Table 1. Non-permanent Employee Discipline Violations and Sanctions in 2019

\begin{tabular}{|c|c|c|c|c|}
\hline \multirow{2}{*}{ Violation } & \multicolumn{4}{|l|}{ Sanctions } \\
\hline & Jan-Mar & Apr-Jun & Jul-Sep & Oct-Dec \\
\hline Coming to work & Verbal & Verbal & Verbal & Verbal \\
\hline $\begin{array}{l}\text { late and or leaving } \\
\text { work prematurely, } \\
\text { according to the } \\
\text { time agreed in the } \\
\text { CLA }\end{array}$ & Rebuke I & Rebuke II & $\begin{array}{l}\text { Rebuke I } \\
\text { and III }\end{array}$ & Rebuke I \\
\hline $\begin{array}{l}\text { Using work time } \\
\text { for counter produc- } \\
\text { tive things } \\
\text { (sleeping, playing } \\
\text { games, in the can- } \\
\text { teen, hindering the } \\
\text { production process, } \\
\text { etc.) }\end{array}$ & $\begin{array}{l}\text { Verbal } \\
\text { Rebuke I }\end{array}$ & $\begin{array}{l}\text { Verbal } \\
\text { Rebuke I }\end{array}$ & $\begin{array}{l}\text { Verbal } \\
\text { Rebuke I }\end{array}$ & \\
\hline $\begin{array}{l}\text { Not coming to work } \\
\text { with a notification } \\
\text { to the boss, on the } \\
\text { other hand his leave } \\
\text { rights have expired }\end{array}$ & $\begin{array}{l}\text { Verbal } \\
\text { Rebuke I }\end{array}$ & $\begin{array}{l}\text { Verbal } \\
\text { Rebuke II }\end{array}$ & $\begin{array}{l}\text { Verbal } \\
\text { Rebuke } \\
\text { IIII }\end{array}$ & \\
\hline $\begin{array}{l}\text { Not attending work } \\
\text { due to illness with- } \\
\text { out a doctor's per- } \\
\text { mission for more } \\
\text { than } 6 \text { days a year }\end{array}$ & & $\begin{array}{l}\text { Verbal } \\
\text { Rebuke I }\end{array}$ & & $\begin{array}{l}\text { Verbal } \\
\text { Rebuke I }\end{array}$ \\
\hline
\end{tabular}

Source: PT PAL Indonesia (Persero)

PT PAL Indonesia (Persero) is a stateowned company engaged in the national defense industry. Industrial relations in the company have been regulated through a Collective Labor Agreement (PKB) between the Human Capital Service Department as the party representing the company (capital owner) and the PAL Workers Union (SP-PAL) as the party representing the workers, which was signed on 18 August 2017. In its implementation, several violations have occurred, including violations of work discipline by non-permanent employees (Specific Time Work Agreement) employees or contract employees, as can be seen in Table 1.

From the table, it can be seen that the employees who have violated the law have been given sanctions in stages by the company. Violations committed more than once a month are given a verbal warning $I$, and if the violation is repeated, a second verbal warning is given, and so on. Employees who continue to violate until they receive a written warning III will then be dismissed (Termination of Employment). The violation as mentioned is a violation of the company's version, in this case the Human Capital Service Department. Meanwhile, on the part of the workers, they accuse companies that have committed violations, where their rights have not been given properly, so that this causes violations of work discipline.
There are several related studies have conducted previously about Human Resource Management (HRM). Sundiman (2017) in his study about Human Resource Management (HRM) in enhancement processes of knowledge management reveals that HRM practice gives initiative in the enhancement process of the knowledge management strategy applied to the company. Furthermore, a study conducted by Cooke et al. (2019) that focused on providing an overview on the state of research in the field in human resource management (HRM) issues in multinational corporations (MNCs) in and from China showed that HRM research in the intercultural, inter- institutional context of MNCs in and from China has the potential to provide contextualized insights for longstanding debates in the field such as HRM standardization versus localization and convergence versus divergence and contextual factors behind these patterns. Meanwhile, a study conducted by Cook (2019) that explored the role of Human Resource Management (HRM) in the context of Jordanian Higher Education (HE) through an evaluation of its application and development showed that the role of HRM is constructive, yet traditional, operational, and underdeveloped in its application. This study also identified a range of unexplored areas of research that call attention to future context-related studies in the field of HRM. Thus, it can be assumed that HRM has an important role in building 
industrial relations to employees.

Based on the explanation and the previous related study above, this purpose of this study is to explore the role of human resource management in fostering industrial relations at PT PAL (Persero).

\section{METHOD}

This study focuses on the role of human resource management, the inhibiting factors and the supporting factors experienced in industrial relations at PT PAL Indonesia (Persero) between management and labor unions, namely: 1) Accommodation stage: a) Supervision in enforcing work discipline; b) Enforcement of work discipline; and c) Duties of management and unions. 2) Cooperation stage: a) Handling employee complaints; b) Parties involved in resolving employee problems and complaints; c) Efforts made regarding violations of work discipline are increasing; and d) Good cooperation forum by management and trade unions. The method used in study is a qualitative method. Furthermore, the data of this study consists of: (1) primary data, obtained from direct interviews with the Head of the Human Capital Service Department, the Head of the Industrial Relations Bureau, and the Industrial Relations Staff as key informants, and the Managers of the Head of the Welfare and Productivity Department of SP-PAL and members of the SP -PAL. PAL as a supporting informant. (2) Secondary data, obtained from various written sources.

\section{RESULT AND DISCUSSION}

PT PAL Indonesia (Persero) has a very high standard of work, making it an international standard company. This standard then requires all employees to have a high level of discipline at work. Every employee at PT PAL Indonesia (Persero) is obligated to comply with the work discipline rules set out in the PKB. Management and SP-PAL respect each other's duties and responsibilities. This is as regulated in Article 7 Paragraph 2:

"Pengusaha dan serikat pekerja SP-PAL wajib saling menghormati tugas kewenangan dan tangung jawab masing-masing pihak sesuai dengan ketentuan peraturan perundangan yang berlaku".

Although the work discipline rules have been stated in the CLA, in its application there are still many violations, especially those committed by non-permanent employees (Bahasa Indonesia: Perjanjian Kerja Waktu Tidak Tetap/PKWTT). These violations include delays, using working hours for counterproductive matters, absenteeism, leave rights that exceed the rules, etc.

Violations of work discipline that occurred at PT PAL Indonesia (Persero) were carried out either by employees directly or indirectly because understanding in understanding the existing rules was different. As a company located in the TNI-AL base area, of course, this should not happen, so in this case the contribution of the management, specifically the Human Capital Service Department, must be optimized. The description in this section will describe the role of human resource management in fostering industrial relations related to the enforcement of work order and discipline which increases through 2 stages as in the focus of research, namely the accommodation stage and the cooperation stage.

\section{Accommodation Stage}

At the initial stage, namely the conflict stage, there was no conflict regarding the establishment of SP-PAL, because management had supported by facilitating the establishment process, so that SP-PAL was formed and declared on May 31, 2000. At the recognition stage, SP-PAL was not only supported, but its existence is also recognized by the company's management. This recognition is contained in the PKB Chapter 2 Articles 7-12 regarding the recognition and facilities of SP-PAL. The CLA also contains rules for work discipline and the process for handling employee complaints, but in practice there are still many violations that are increasing and are carried out by nonpermanent employees (Bahasa Indonesia: Perjanjian Kerja Waktu Tidak Tetap/PKWTT). This violation creates a problem that requires an accommodation action from the Human Capital Service Department. The accommodation in question is an effort made by management regarding the problems that occur.

The accommodation stage is the stage where the existence of a trade union is no longer seen as a barrier in employment relations and even takes advantage of the positive role of trade unions in the organization. Trade unions are considered by human resource management as partners who bridge between workers and management in enforcing work discipline and directing workers' attitudes and behavior policies. In addition, it is also a work liaison, and management takes advantage of this to resolve 
existing complaints through regular communication to create good industrial relations. At this stage, management carries out supervision and efforts that must be carried out in accordance with the provisions or rules that have been determined together with management and the union. At the accommodation stage, which is in accordance with the conditions in the field, has indicators, namely:

Supervision in enforcing work discipline must comply with applicable regulations. Based on the facts on the ground, it shows that the supervision in enforcing work discipline is in accordance with the mutually agreed rules. In writing, it is not explained who has the right to supervise, but the duties and authority are fully in the management, specifically the Human Capital Service Department, as expressed by Mrs. Yayuk Djuniati as Head of Department. Dept. of Human Capital Service as follows:

"Pengawasan itu semua harus korek terhadap disiplin. Hanya wewenang sebenarnya ada pada Tim Task Force atau keamanan karena mereka yang mengawasi dan melakukan patroli. Kemudian setiap hari mereka akan melaporkan kepada pihak manajemen untuk kita rekap" (Interview results dated April 9, 2020).

This is also confirmed by Mr. Moch. Nafie as a member of SP-PAL as follows:

"Pengawasan penegakkan disiplin itu tugasnya manajemen SDM atau di PAL itu HCM. Dalam pengawasan itu HCM membentuk tim untuk patroli namanya Task Force (Satuan Tugas) dari Divisi Kawasan Departemen Keamanan yang isinya satgam kemudian berkoordinasi dengan HCM tugasnya itu berpatroli dan mencatat semua jenis pelanggaran setiap hari lalu dilaporkan ke HCM" (Interview results dated April 19, 2020).

In addition, the management also involves SP-PAL in the supervision of work discipline. The involvement of SP-PAL in enforcing work discipline if asked for assistance by management. SP-PAL is only a function of control and partners, so it cannot be directly involved in its implementation, but if there are things that deviate from employees, they can convey it to management, as stated by $\mathrm{Mr}$. Dept. JahProd SP-PAL.

"Iya mba, jadi begini SP-PAL itu sebenarnya menjadi fungsi control dan mitra dalam hal ini. Secara fungsi control SP-PAL tidak dapat menyentuh dalam pelaksanaan itu namun apabila terdapat hal-hal yang kurang ideal, kita dapat sampaikan secara official kepada jajaran manajemen. Baru yang mengoreksi itu pihak pelaksanaan yaitu manajemen" (Interview result dated April 21, 2020).

From the interview above, it shows that management has carried out its duties and authorities in supervising the enforcement of work discipline through coordination with the Security Team (Task Force) to patrol every day, as well as SP-PAL based on mutually agreed duties and rules. All employees of PT PAL Indonesia (Persero) are also entitled to supervise the enforcement of work discipline to ensure that management is fair in conducting supervision.

Enforcement of work discipline is one of the efforts made by management to improve existing values and create a climate of justice and consistency within the company by providing sanctions according to the type of violation committed. This is also in accordance with the situation on the ground, where the efforts made by the Human Capital Service Department provide sanctions if employees commit violations according to the type of violation. Enforcement of work discipline is carried out by Ankum or the concerned superior because the discipline development at PT PAL Indonesia (Persero) is in their respective divisions, as expressed by Mrs. Yayuk Juniati as Head of Dept. of Human Capital Services.

"Kami itu dalam penegakkan tata tertib levelnya berjenjang. Manajemen mengingatkan kepada atasannya yang tidak menegakkan disiplin di lingkungannya sehingga memberikan teguran: 'iniloh ada karyawanmu yang begini-begini, tolong untuk ditegur'. Lepas dari koordinasi mengingatkan kalau ankumnya tidak melakukan suatu tindakan maka yang melakukan tindakan HCM kepada ankumnya bukan kepada pelanggar" (Interview results April 09, 2020).

Management gives a warning to superiors in the form of a warning letter of sanctions. The sanctions given by the management are also stratified. The procedure for giving a warning is if the related violation is a maximum of two times and continues to be graded, as stated by Mrs. Ayu Rahadjeng as Head of Industrial Relations Bureau.

"Jadi setiap hari manajemen itu dapat laporan karyawan yang terlambat maupun pelanggaran lain dari Tim Keamanan. Kemudian manajemen akan rekap mana yang misal terlambat lebih dari $2 x$ atau pelanggaran apapun diakhir bulan akan diberikan form teguran kepada yang bersangkutan tembusan dari atasan, lalu karyawan yang bersangkutan akan dipanggil oleh atasannya untuk dikasih arahan gitu, kemudian tanda tangan di form teguran dan nanti dikembalikan lagi ke manajemen untuk direkap, terus hingga tegurannya bertingkat" (Interview results dated February 19, 2020).

If the sanctions given to employees are not considered until the realm of dismissal 
sanctions, they are not immediately laid off but involve SP-PAL. The involvement of SP-PAL in approaching employees who violate it, because it is the obligation of SP-PAL as a partner with the company to enforce work discipline. Management will contact SP-PAL if there are violations that must be followed up with a personal approach to identify. This was expressed by Mrs. Yayuk Juniati as Head of Dept. of Human Capital Services.

"Iya harus itu juga termasuk kewajiban SP-PAL sebagai mitra dengan perusahaan untuk menegakkan disiplin kerja. Manajemen komunikasinya juga ke SP-PAL misal konfirmasi mengenai penyebab karyawan melanggar biasanya atasan dibantu oleh SP-PAL. SP-PAL membantu dalam mengulik karyawan mengenai hal personal"' (Interview results on April 9, 2020).

From the description above, it can be concluded that the management has implemented fair work discipline enforcement based on existing rules through the provision of multilevel warning sanctions in coordination with the Direct Supervisor and has involved the positive role of SP-PAL by taking a personal approach to explore life or individual employees.

Responsibilities of management and trade unions in enforcing work discipline. The scope of industrial relations within the company consists of management and labor unions, both of which have obligations that must be carried out to foster industrial relations by enforcing work discipline. This is in accordance with what is in the field, so far the management and SP-PAL have carried out their obligations well though. The management, to be precise, the Human Capital Service Department has acted in accordance with the existing rules. Regarding the enforcement of work discipline by giving multilevel warning sanctions because management realizes that if management is negligent in this case it will affect other things and even harm the company. In addition, management's obligation is to be responsible for reporting on work discipline and employee complaints to the Manpower Office, as stated by Mrs. Yayuk Juniati as Ka. Dept. of Human Capital Services

"Sudah mbak salah satunya dengan bertindak sesuai dengan aturan yang ada. Terkait penegakkan disiplin kewajiban manajemen memberikan sanksi yang berjenjang. Penegakkan itu juga penting jika tidak disikapi dengan tegas maka akan berimbas kepada hal yang, tidak dapat menyelesaikan pekerjaan sesuai deadline, merugikan perusahaan dan lain sebagainya. Manajemen juga harus melaporkan disiplin kerja atau keluhan karyawan ke Disnaker. Kalau tidak melakukan kewajibannya apa yang harus dilaporkan, adanya pihak manajemen yang akan mendapat laporan nantinya" (Interview results dated April 09, 2020).

Enforcement of work discipline also involves SP-PAL as a working partner of management. This is also stated in the Collective Labor Agreement Article 7 paragraph 8 . SP-PAL can provide suggestions/ considerations in the context of increasing productivity, company growth and worker welfare. SP-PAL's obligation is that if the employee is right SP-PAL will defend, but if proven wrong then SP-PAL also realizes that according to the existing rules without abusing his authority and placing the rules according to the portion of the rules. This was stated by Mr. Fajar Nur Cahyo as the Ka's Manager. Dept. JahProd SP-PAL.

"SP-PAL itukan sebagai mitra dari manajemen dimana keberlangsungan perusahaan ini menjadi tanggung jawab SP-PAL. Jadi intinya SP-PAL ini tidak hanya menuntut tapi mempunyai beban moral untuk keberlangsungan perusahaan salah satunya harus mampu mengarahkan anggotanya untuk menaati aturan perusahaan dan menjadi keberlangsungan produktivitas perusahaan. SP$P A L$ tidak membela anggotanya sewenang-wenang, namun SP-PAL berusaha mendudukan aturan itu secara porsinya" (Interview, April 21, 2020).

From the explanation above, it can be concluded that the management's obligation related to the enforcement of work discipline is to give a warning sanction in accordance with the applicable rules because it is also the responsibility of a management to report it to a party outside the company, namely the Manpower Office, while the obligation of SPPAL is as a partner. From management must help direct employees to obey company rules and not defend employees blindly but put the rules according to their portion.

\section{Cooperation Stage}

In the cooperation stage, there is an increase in working relations in accordance with expectations between the company and the labor union in industrial relations. Trade unions have played a role in increasing employee productivity and performance so as to trigger morale. At the stage of cooperation, it is in accordance with the conditions in the field, the stage of cooperation also has indicators:

Handling employee complaints is the management's way of dealing with employee complaints. its handling must be seen as an effort to improve the quality and performance of employees which will create harmonious 
industrial relations. The Human Capital Service Department has made a policy regarding the submission of complaints carried out in stages. This is regulated in Article 121 of the CLA. This is as regulated in Article 121 Paragraph 2:

"Submission of complaints can be submitted verbally or directly to superiors in stages, if no response is received, complaints can be submitted to higher superiors or to SP-PAL"

If the complaint cannot be found a solution, it will be submitted to management to be resolved by deliberation. This was also confirmed by Mr. Fajar Nur Cahyo as the Chief Executive. Dept. JahProd SP-PAL.

"Tahapannya itu dari karyawan divisi terkait itu menyampaikan kepada pengurus unit SP-PAL. Kemudian pengurus unit SP-PAL memfasilitasi apabila keluhan itu berkenaan dengan jajaran manajemen di divisi terkait dan diselesaikan secara internal di divisi masing-masing. Sekiranya permasalahnnya belum dapat diselesaikan $d i$ manajemen divisi maka SP-PAL unit bisa membawanya ke pusat. SP-PAL baru menyampaikan ke manajemen pusat tepatnya HCM \& CM untuk diselesaikan" (Interview on April 21, 2020).

Parties involved in resolving employee problems and complaints. Problems that occur in the company's environment related to industrial relations are known as industrial relations disputes. Industrial relations disputes have been included in Law No. 2 of 2014 concerning the settlement of industrial relations (Undang-Undang Tahun 2004 No. 2 mengenai Penyelesaian Perselisihan Hubungan Industrial). PT PAL Indonesia (Persero) in solving problems related to the enforcement of work discipline is the authority of the management, specifically the Human Capital Service Department, which is carried out through the internal company first, through verbal communication, as stated by Mr. Moch. Nafie as a member of SP-PAL.

"Kalau penyelesaian itu diserahkan ke pihak manajemen atau HCM. Namun ada keterlibatan Tim Keamanan dan atasan yang bersangkutan cuma mereka tidak bisa berbuat lebih karena semua jenis pelanggaran yang membuat punismentnya orang HCM. Kemudian ada Serikat Pekerja yang berkewajiban membantu" (interview 19 April 2020).

Efforts made regarding violations of work discipline are increasing. The impact arising from a violation of work discipline as stipulated in the CLA results in disharmony in industrial relations, thus affecting work productivity and employee promotions. Regarding the violation of work discipline, the efforts made by management are: First, by holding socialization counseling and direction by showing data on work discipline violations to all Division Heads to provide direction to each of their employees, as stated by Mrs. Ayu Rahadjeng as Ka. Industrial Relations Bureau:

"Memang PT. PAL Indonesia (Persero) pada tahun ini terjadi pelanggaran tata tertib di setiap tahunnya dan mengalami peningkatan. Kemarin memang sampai ada meeting, dipanggillah semua Kadiv karena laporan dari bagian keamanan sampai ke Direktur Utama Sumber Daya dan Umum hingga beliau marah karena kebanyakan pelanggaran dilakukan oleh PKWT. Dilakukan pengarahan dan sosialisasi selama satu minggu apakah mereka berniat diangkat menjadi PKWTT sampai membahas kearah sana. Jadi yang dilakukan manajemen saat itu selain pengarahan langsung yaitu melakukan sosialisasi mengumpulkan seluruh kepala divisi, kemudian rapat dengan SP-PAL terkait mengarahkan perilaku pekerja agar bekerja sesuai aturan dan lebih ditekankan lagi kepada karyawan agar tidak melanggar lagi" (interview on February 19, 2020)

In this case, management reports to the President Director of Human Resources to provide direct direction in order to provide a deterrent effect and its influence on the employee himself. Violations of work discipline that continue to be carried out will certainly affect the promotion or appointment of employee status, because the results of violations committed will be accumulated every period by management as material for evaluation and performance appraisal, for example on non-permanent employees will have an impact on the process of appointing permanent employees as well as promotions to positions they wish to carry out. promoted. This was confirmed by Mrs. Ayu Rahadjeng as $\mathrm{Ka}$. Industrial Relations Bureau:

"Jelas berdampak terutama kita pakai pada saat proses pengangkatan karyawan PKWTT, kita akan lihat seberapa sering melakukan pelanggaran dan jenis pelanggaran apa itu akan menjadi evaluasi dan penilaian kinerja juga. Kemudian proses promosi yang mau diangkat menjadi misal kepala biro atau kepada departemen gitu" (interview on February 19, 2020).

From the explanation above, it can be concluded that the precise management of the Human Capital Service Department has not only carried out its obligations by enforcing work discipline and providing sanctions for reprimand, related to the level of violation of work discipline by holding directives, socializing the existing regulations in PKB to create employee awareness so as to create discipline and harmonious industrial relations.

Cooperation forum between management and trade unions. The cooperation forum that 
must be carried out by management as company representatives and SP-PAL as representatives of employees is a bipartite communication forum. Bipartite is the most important thing that is applied at PT PAL Indonesia (Persero) when there is a process of resolving violations and all other forms of problems that must be resolved internally by the company because with this forum in fostering industrial relations it can create harmonious industrial relations. In addition, other cooperation forums can be held at PT PAL Indonesia (Persero) with the aim that management and SP-PAL can continue to synergize through several informal activities, as stated by Mrs. Ayu Rahadjeng as Ka. Industrial Relations Bureau:

"Bipartit sering dilakukan karena kan forum komunikasi dengan SP-PAL ya jadi dilakukan pada saat penyelesaian pelanggaran dan permasalahan lain. Contohnya sebelum sanksi PHK kita tidak langsung mem-PHK, namun dibawalah ke forum bipartite dengan SP-PAL" (interview on February 19, 2020).

From the interview explanation above, it can be concluded that the management of the Human Capital Service Department has always prioritized a bipartite forum between management and SP-PAL with gradual communication so that all problems are attempted to be internal to the company. And there are other informal cooperation forums by holding meetings such as Coffee Breaks and training programs.

\section{The Role of the Human Capital Service Department in Fostering Industrial Relations}

The Human Capital Service Department has realized its function in fostering industrial relations. In general, industrial relations is meant to deal with work relations problems that occur within the company, this is also a separate task for human resource management. The role of the Human Capital Service Department has contributed greatly to the improvement of human resources, especially regarding the development of industrial relations so as to create a comfortable working relationship for employees. Comfortable working conditions will certainly affect the improvement of HR competencies because in this case the management has given special attention to its employees.

The role of the Human Capital Service Department has been at the cooperation stage where management has taken advantage of the positive role of the existence of a labor union in the company, namely SP-PAL which is a work partner of management to direct employee behavior and work discipline. The involvement of SP-PAL which takes a personal approach to employees who commit violations and facilitates and protects employees, of course with the existing rules, it is not arbitrary in using its power.

Supervision of work discipline is carried out by the security team which is tasked with patrolling, recording and reporting to the Human Capital Service Department for recap when enforcing work discipline because the Human Capital Service Department is obliged to provide a form of reprimand according to the type of violation committed. It is also an evaluation material for management in assessing the performance and competence of its employees. The result of the collaboration between management and SP-PAL is that the PKB has been formed on August 18, 2017. This PKB is always updated every two months as a guideline in creating productive working conditions at PT PAL Indonesia (Persero). In addition to handling complaints, the Human Capital Service Department provides a policy in stages where all forms of complaints will be facilitated and accommodated by SP-PAL and submitted to the Direct Supervisor so that complaints can be found immediately in order to achieve effectiveness in problems. If the problem still has not found a solution, the superior and SP-PAL will bring it to the Human Capital Service Department to be communicated by deliberation and consensus through a bipartite communication forum without involving a third party. In addition, to maintain synergistic cooperation, the Human Capital Service Department held Coffee Breaks, socialization counseling and even coaching with direct superiors and SP-PAL.

Inhibiting and Encouraging Factors in Fostering Industrial Relations at PT PAL Indonesia (Persero)

The inhibiting and supporting factors in fostering industrial relations in this study were to be able to see the supporting factors for the role of human resource management in fostering industrial relations:

Driving factor

Supervision through the security team (task force);

Enforcement by imposing sanctions according to the type of violation;

Complaints are handled in stages;

Resolution with verbal communication; and 


\section{Bipartite cooperation forum.}

Inhibiting factors, namely the handling of complaints and settlements caused by the number of non permanent employees (Bahasa Indonesia: Perjanjian Kerja Waktu Tidak Tetap/PKWTT) who violate.

Thus, the inhibiting factor experienced by management related to industrial relations development is the second variable with indicators for handling employee complaints where violations are mostly committed by nonpermanent employees (Bahasa Indonesia: Perjanjian Kerja Waktu Tidak Tetap/PKWTT) who have different attitudes of commitment and understanding regarding the applicable rules.

\section{Stage Theory Analysis}

The role of human resource management related to fostering industrial relations in its implementation cannot stand alone because in general the parties involved in industrial relations at the company level are management and workers or workers who are members of trade unions. The management, in particular, the Human Capital Service Department, also coordinates with the Direct Supervisor as the management representative at the respective divisional level for industrial relations. The role of management benefits from each indicator variable, while industrial relations in general also benefits from the cooperation carried out within the company. Each variable has its own strength in providing benefits to PT PAL Indonesia (Persero). The cooperation variable gives the biggest contribution in creating industrial relations because the parties involved have synergized with each other to achieve company goals and create a comfortable working relationship at PT PAL Indonesia (Persero).

\section{CONCLUSION}

Based on the description of the results of the data analysis above, it can be concluded that in general industrial relations problems regarding employee rights are not fulfilled but the problems that occur at PT PAL Indonesia (Persero) regarding violations of work discipline are increasing. The role of human resource management, specifically the Human Capital Service Department at PT PAL Indonesia (Persero) in industrial relations related to the problems that occur, has been successfully fostered by providing policies related to submitting employee complaints in stages through superiors first and accompanied by SP-PAL. All forms of problems regarding industrial relations always prioritize bipartite communication with SP-PAL. The existence of SP-PAL is a driving factor in fostering industrial relations, each party, both management and SP-PAL, has understood its role in directing worker behavior. The important findings in this study are still found to be inhibiting factors, namely aspects of handling employee complaints where violations that occur are still mostly committed by non-permanent employees (Bahasa Indonesia: Perjanjian Kerja Waktu Tidak Tetap/PKWTT) due to lack of understanding regarding the rules that apply in work agreements and $\mathrm{PKB}$.

\section{REFERENCES}

Cook, C. (2019). The Role of Human Resource Management in the Context of Jordanian Higher Education: A Study of the Literature. Journal of Organizational Psychology, 19 (6). https://doi.org/10.33423/jop.v19i6.2660

Cooke, F. L., Liu, M., Liu, L. A., \& Chen, C. C. (2019). Human Resource Management and Industrial Relations in Multinational Corporations in and from China: Challenges and New Insights. Human Resource Management, 58(5), 455-471. https:// doi.org/10.1002/hrm.21986

Kaufman, B. E. (2001). Human Resources and Industrial Relations. Human Resource Management Review, 11(4), 339-374. https://doi.org/10.1016/S1053-4822(01) 00045-6

Simanjutak, P. (2003). Manajemen Hubungan Industrial. Jakarta: Pustaka Sinar Harapan.

Sundiman, D. (2017). Human Resource Management in the Enhancement Processes of Knowledge Management. Binus Business Review, 8(3), 167. https://doi.org/10.21512/ bbr.v8i3.3708

Undang-Undang Tahun 2004 No. 2 mengenai Penyelesaian Perselisihan Hubungan Industrial. 